Animal Health Research Institute Assiut Regional Laboratory

\title{
STUDIES ON SOME BLOOD PARASITES OF DOGS IN ASSIUT GOVERNORATE WITH SPECIAL REFERENCE TO MICROFILARIAE
}

(With 5 Tables and 2 Plates)

By

G.A. TAHER, GEHAN M. SAYED and M.I. ARAFA

(Received at 15/3/2010)

دراسات على بعض طفيليات الام في الكلاب بمحافظة أسيوط وخاصه

\section{جمال امين طاهر ، جيهان محمد سيل ، محسن إبراهيم عرفه}

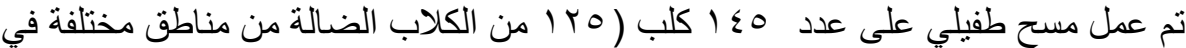

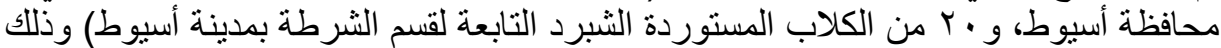

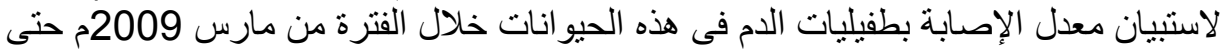

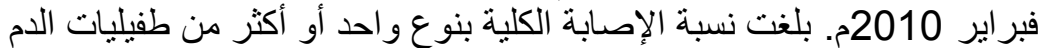

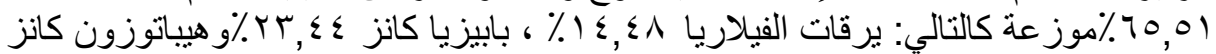

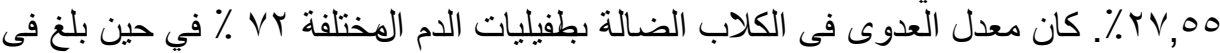

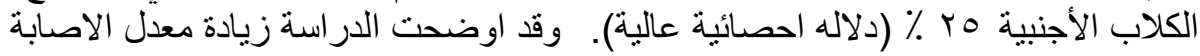

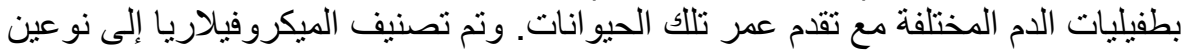

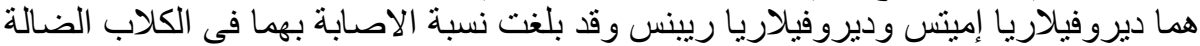

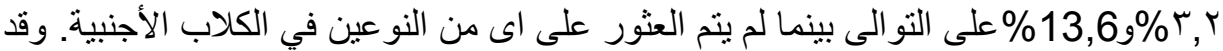

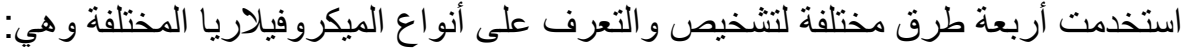

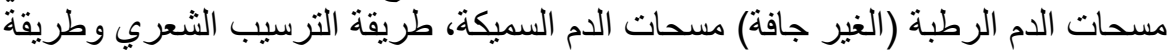

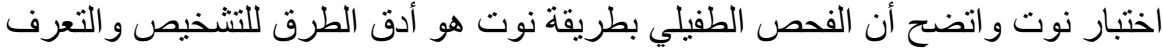

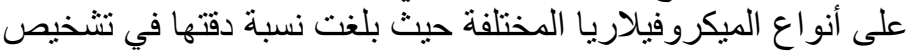

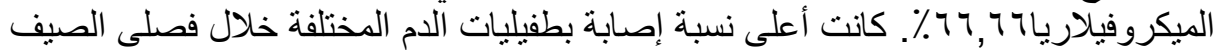

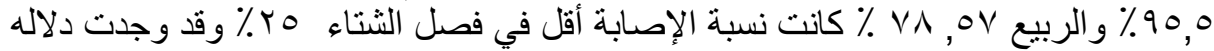

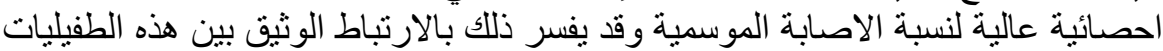
و انتشار وتكاثر الحشرات الناقلة للطفيليات في هذا الوقت من السنة.

\section{SUMMARY}

A parasitological survey was carried out on 145 dogs (125 stray dogs from different localities in Assiut Governorate and 20 foreign breed Shephered dogs in the security unit at Assiut city) to estimate the 
prevalence of different blood parasites during the period from March 2009 till February 2010. Out of 145 examined dogs 95 (65.51\%) were infected with one or more parasitic species, 21 (14.48\%) were positive for microfilariae, 34 (23.44\%) with Babesia canis and 40 (27.58\%) with Hepatozoon canis. The infection rate of stray dogs with different blood parasites was $72 \%$ while in foreign breed dogs was $25 \%$ (statistically highly significant). Mixed infection by more than one blood parasite was detected in 19 dogs. Two types of microfilariae were detected in examined animals: Dirofilaria immitis and Dirofilaria repens and their infection rate in stray dogs was $3.2 \%$ and $13.6 \%$ respectively. No microfilariae were detected in the blood films of foreign breed ones. Four methods were used in this study for the diagnosis of microfilariae: direct wet method, thick blood smears, capillary sedimentation technique and modified Knott's method. The modified Knott's test was the most reliable test, its sensitivity was $66.66 \%$. The present work cleared that the incidence of infection of dogs with different blood parasites increased with age in both breeds. The highest rate of infection with different blood parasites was recorded during Summer (95.5\%) and Spring (78.6\%) while the lowest rate in Winter (25\%).Seasonal variations were found statistically highly significant and this may be due to correlation between the infestation rate and the flourishing of the insect population and tick infestation during this period of the year.

Key words: Dog, blood parasites, microfilariae, prevalence.

\section{INTRODUCTION}

Dogs not only act as a dangerous reservoir host for most of the parasitic diseases but also they play a role in transmission of a number of important pathogens among domestic animals and human being that deteriorate their health and lead to enormous losses.

Dogs suffer from a variety of blood parasites as: Babesia (intraerythrocytic protozoa), Hepatozoon (intra - leukocytic protozoa), Trypanosoma (inter-erythrocytic protozoa) and filarial worms (Gadahi et al., 2008).

Heartworm disease in dogs and related canines is caused by a filarial nematode (a large thread-like round worm), Dirofilaria immitis. The adult worms live in the right side of the heart (right ventricle) and adjacent blood vessels (pulmonary arteries), and because of their location, are commonly called dog heartworms. It is particularly common in the tropics and subtropics. It seems that all breeds of dogs 
are equally susceptible (Retnasapathy and San 1976). It is also of public health importance because it often produces nodules in the pulmonary parenchyma and subcutaneous tissue or even the eyes of humans (Seo Youngwoo et al., 2001).

Dirofilaria repens is commonly found in the subcutaneous tissue of dogs in Southern Europe, Africa and Asia (Zahler et al., 1997). Subcutaneous and subconjunctival migration of immature nematodes has been reported in human beings (Pampiglione et al., 1995).

Both dirofilariasis due to $D$. immitis and D. repens are transmitted by the bite of anopheline and culicine mosquitoes harboring the infective third stage larvae.

In epizootiologic surveys of dirofilariasis in dogs, various methods for determining infection status have been used. These have included microscopic examination of blood smears, blood sample concentration techniques (e.g Knott's test) for detecting circulating microfilariae, examination for identifying adult worms at necropsy, radiographic and angiographic evaluations (Knight, 1977 and Thrall et al., 1980).

Babesia spp. parasitize erythrocytes, causing anemia in dogs. Different species exist with varying host specificity. B. canis and B. gibsoni are two organisms commonly known to infect dogs. B. canis is commonly known to infect dogs and it is comparatively highly pathogenic for both young and old dogs. It is found throughout Asia, Africa, Europe, the Middle East, and North America (Levine, 1985).

Hepatozoon is a genus of protozoa belonging to phylum Apicomplexa. Dogs are known to be susceptible to infection by Hepatozooon canis and Hepatozoon americanum. The detection of capsule-like gamonts in the cytoplasm of neutrophils in blood smears is helpful for diagnosing hepatozoonosis (Baneth et al., 2001).

Both Babesia and Hepatozoon parasites are transmitted by ticks in which sexual stages occur (Levine, 1961).

In Egypt dog's blood parasites were studied previously by several authors (Botros et al., 1973, Sakla, 1975, Amer, 1986, Mahmoud, 1998 and Abd -el Rahim, 1998).

The aim of the present work is to throw further light on some of the blood parasitic diseases infecting dogs in Assiut Governorate with special reference to microfilariae which have pubic health hazards (zoonotic importance). In addition, to evaluate the sensitivity of different techniques used for diagnosis of microfilariae.

\section{MATERIALS and METHODS}




\section{Animals}

During the period from March 2009 to February 2010, one hundred and fourty five dogs (125 stray dogs from different localities in Assiut Governorate and 20 foreign breed Shephered dogs in the security unit at Assiut Governorate, upper Egypt) aged between 6 months and over 7 years old were used in this study.

\section{Sampling:}

$5 \mathrm{ml}$ of blood was drained from each dog from the cephalic vein in vacum tubes for blood parasite examination.

Parasitological examination: Four parasitological techniques were done for detection of the most reliable one for diagnosis of microfilariae.

- Fresh blood was examined for detection of motile microfilariae with direct wet smear method (Levine, 1985).

- Haematocrit centrifugation technique and Knott's technique were done for detection of mild microfilaraemia (Lowernce \& Thomas, 1987).

- Blood films (thin and thick) were prepared from fresh blood, fixed by absolute methyl alcohol, stained by Giemsa stain and examined by light microscope for detection of different blood parasites.

- The detected parasites were microphotographed and identified according to the description given by Levine (1985) and Soulsby (1986).

- The average dimensions of various anatomical regions were determined by eyepiece micrometer. Seasonal investigation of the detected blood parasites was done.

Postmortem examination: Infected dogs were thoroughly examined for adult Dirofilaria immitis and Dirofilaria repens during necropsy in the Veterinary Medical Hospital of Assiut Governorate.

Statistical analysis: Obtained data were subjected to a software program (SPSS) according to Borenstein et al. (1997).

\section{RESULTS}

Out of 145 examined dogs $95(65.51 \%)$ were infected with one or more parasitic species, $21(14.48 \%)$ were positive for microfilariae, $34(23.44 \%)$ with Babesia canis and 40 (27.58\%) with Hepatozoon canis. The infection rate of stray dogs with different blood parasites was $72 \%$ while in foreign breed dogs was $25 \%$. Mixed infection by more than one blood parasite was detected in 19 dogs (18 stray dogs and 1 foreign breed dog). 
Two types of microfilariae were detected in examined animals: Dirofilaria immitis and Dirofilaria repens and their infection rate were $2.75 \%$ and $11.72 \%$ respectively. Both types of microfilariae were detected in the blood films of stray dogs only (Table 1). Mixed infection with the two types of microfilariae was recorded in 3 stray dogs.

Data concerning the seasonal variation and the effect of age on the rate of infection with different blood parasites are shown in (Table 2 and 3).

\section{Blood parasites detected in the peripheral blood of dogs are: 1- Dirofilaria immitis microfilariae:}

Out of 125 examined stray dogs, $4(3.2 \%)$ were positive for $D$. immitis microfilariae. The microfilaria was unsheathed. It is characterized by a tapered cranial end, straight caudal end and a straight body shape. The body cavity was filled with a large number of minute oval deeply stained nuclei appeared as one mass interrupted at certain anatomical landmarks (Plate 1, Table 4). Their total length ranged from $291.6-346.66 \mu \mathrm{m}(325 \mu \mathrm{m})$ and their width ranged from $5.4-7.2 \mu \mathrm{m}$ $(6.75 \mu \mathrm{m})$.

\section{2- Dirofilaria repens microfilariae:}

It was detected in $17(13.6 \%)$ of examined stray dogs. The microfilaria was non sheashed and lie in graceful curves in stained blood smears. It had a blunt cranial end, a button shaped caudal end and a cresentic shaped body. A single row of somatic nuclei is faint stained throughout the whole length of the body of the microfilariae which appeared as spiral shaped line. The somatic nuclei clump together but not mask the anatomical landmarks in most cases of the microfilariae. Their total length ranged from $289-330 \mu \mathrm{m}(310 \mu \mathrm{m})$ and their width ranged from 3.75: $6.25 \mu \mathrm{m}(5.75 \mu \mathrm{m})$.

The microfilarial landmarks were detected in the form of interruptions in the column of nuclei (Plate 1, Table 4).

The result of the comparative sensitivity of different techniques used for the detection of the microfilariae indicated that modified Knott's technique is the most sensitive technique $(66.66 \%)$ followed by wet blood film technique (42.85\%), thick blood film $(33.33 \%)$ and haematocrit centrifugation (28.57\%) (Table 5).

Routine P.M examinations of 100 dogs at the veterinary clinical hospital in Assiut University failed to detect any adult worms. 


\section{3- Babesia canis:}

Out of 145 examined dogs, $34(23.44 \%)$ were positive for Babesia canis. The incidence was $24 \%$ and $20 \%$ among stray and foreign breeds dogs respectively (Table 1)

Various forms of Babesia canis have been detected in the peripheral blood of dogs. Ovoid shaped mostly single or multiple. It had one marginally located chromatin mass in addition to central vacuole. It measured 3.5: $4.7 \mu \mathrm{m}$ in length by 2.1: $2.8 \mu \mathrm{m}$ in width (average 3.8: 2.4 $\mu \mathrm{m})$ (Plate 2, Fig. 2).Amoeboid forms measured 3.5: $4.8 \mu \mathrm{m}$ in length by 2: $3.4 \mu \mathrm{m}$ in width. Centrally located vacuoles are commonly seen (Plate 2 Fig. 1). Pyriform or pear shaped forms are commonly detected. They are found in pairs and less frequently in single infection. They measured from $3.5 \mu \mathrm{m}$ in length by $2: 2.6 \mu \mathrm{m}$ breadth (Plate 2 Fig. 3 ).

\section{4- Hepatozoon canis}

Out of 145 examined dogs 40 (27.58\%) dogs were infected with Hepatozoon canis. The incidence was $31.2 \%$ and $5 \%$ among stray dogs and foreign breed ones respectively (Table 1).

\section{Morphological observations of gametocytes: A- Macrogametocytes}

These are ovoidal bodies with blunt rounded ends measuring 9: $11 \mu \mathrm{m}$ long and 5: $7.5 \mu \mathrm{m}$ wide. The centrally located nucleus is large compact strippled and spherical. The cytoplasm is granular and stains dark blue with Giemsa stain. Macrogametocytes are surrounded by delicate fine capsule. (Plate 2 Fig. 4,5).

\section{B- Microgametocytes}

They are elongate, rectangular, sausage shaped bodies with blunt rounded ends measuring 8.5-11.2 $\mu \mathrm{m}$ long by 3.4- $4.8 \mu \mathrm{m}$ wide, they stain pale blue with Giemsa stain. The nucleus is large, compact and strippled and is usually located at one pole of the parasite. The microgametocytes are enveloped by delicate fine capsules. On several occasions microgametocytes were found to lie within the nuclear substance of the polymorphnuclear leucocytes. (Plate 2, Fig. 6). Sometimes the parasite was found to lie within the cytoplasm of the host cell. Free gametocytes devoid of their capsules were usually encountered anywhere out side the host cell. 
Table 1: Prevalence of different blood parasites in examined dogs.

\begin{tabular}{|c|c|c|c|c|c|c|c|}
\hline & \multirow{2}{*}{ Examined dogs } & \multirow{2}{*}{$\begin{array}{c}\text { No. } \\
\text { examined }\end{array}$} & \multirow{2}{*}{$\begin{array}{c}\text { No. } \\
\text { infected }\end{array}$} & \multirow{2}{*}{$\%$} & \multicolumn{4}{|c|}{ Microfilariae } \\
\cline { 5 - 9 } & & & $\begin{array}{c}\text { Diro. } \\
\text { immitis }\end{array}$ & $\%$ & $\begin{array}{c}\text { Diro. } \\
\text { repens }\end{array}$ & $\%$ \\
\hline $\begin{array}{c}\text { Stray dogs } \\
\text { (local breeds) }\end{array}$ & 125 & 90 & 72 & 4 & 3.2 & 17 & 13.6 \\
\hline Foreign breeds & 20 & 5 & 25 & - & - & - & - \\
\hline Total animals & 145 & 95 & 65.5 & 4 & 2.75 & 17 & 11.72 \\
\hline
\end{tabular}

Data were found statistically highly significant.

Chi square 16.85

$\mathrm{P}$ (probability) $<0.0001$

Table 2: Relation between the age and the prevalence rate of infection with dog's blood parasites

\begin{tabular}{|c|c|c|c|c|c|c|c|}
\hline \multirow{2}{*}{$\begin{array}{c}\text { Age of } \\
\text { examined } \\
\text { dogs }\end{array}$} & \multirow{2}{*}{$\begin{array}{c}\text { No. } \\
\text { examined } \\
\text { dogs }\end{array}$} & \multirow{2}{*}{$\begin{array}{l}\text { No. } \\
\text { infected }\end{array}$} & \multirow[t]{2}{*}{$\%$} & \multicolumn{4}{|c|}{ Microfilariae } \\
\hline & & & & $\begin{array}{l}\text { Dirofilaria. } \\
\text { immitis }\end{array}$ & $\%$ & $\begin{array}{c}\text { Dirofil. } \\
\text { repens }\end{array}$ & $\%$ \\
\hline $\begin{array}{l}0.6: 3 \\
\text { years }\end{array}$ & 30 & 15 & 50 & - & - & 2 & 6.66 \\
\hline $\begin{array}{c}4: 6 \\
\text { years }\end{array}$ & 55 & 35 & 63.63 & 1 & 1.8 & 6 & 10.9 \\
\hline $\begin{array}{l}\text { Over } 7 \\
\text { years }\end{array}$ & 60 & 45 & 75 & 3 & 6.66 & 9 & 15 \\
\hline
\end{tabular}


Table 3: Seasonal prevalence of dog's blood parasites.

\begin{tabular}{|c|c|c|c|c|c|c|c|c|}
\hline \multirow{3}{*}{ Season } & \multirow{3}{*}{$\begin{array}{c}* * \text { Total } \\
\text { examined }\end{array}$} & & & & & \multicolumn{3}{|c|}{ Infected dogs } \\
\hline & & \multicolumn{6}{|c|}{ Microfilariae } & \multirow{2}{*}{$\begin{array}{c}\text { B. } \\
\text { cani }\end{array}$} \\
\hline & & $\begin{array}{c}\text { Dirofilaria. } \\
\text { immitis }\end{array}$ & $\%$ & $\begin{array}{c}\text { Dirofilaria. } \\
\text { repens }\end{array}$ & $\%$ & Total & $\%$ & \\
\hline Autumn & 30 & 1 & 3.33 & 2 & 6.66 & 3 & 10 & 4 \\
\hline Winter & 28 & - & - & - & - & - & - & 3 \\
\hline Spring & 42 & 2 & 4.76 & 6 & 14.28 & 8 & 19 & 12 \\
\hline Summer & 45 & 1 & 2.22 & 9 & 20 & 10 & 22.22 & 15 \\
\hline Total & 145 & 4 & 2.75 & 17 & 11.72 & 21 & 14.48 & 34 \\
\hline
\end{tabular}

Highly significant statistical variations between seasons and prevalence of infection.

Chi square 50.133

(probability) $<0.00001$ 
Table 4: Measurements of Dirofilaria immitis and Dirofilaria repens microfilariae landmarks in micron Giemsa stained.

\begin{tabular}{|l|c|c|c|c|}
\hline \multirow{2}{*}{} & \multicolumn{2}{|c|}{ Dirofilaria immitis } & \multicolumn{2}{c|}{ Dirofilaria repens } \\
\cline { 2 - 5 } & Range & Mean & Range & Mean \\
\hline Total length & $291.6: 346.66$ & 325 & $289: 330$ & 310 \\
\hline Width & $5.4: 7.2$ & 6.75 & $3.75: 6.25$ & 5.75 \\
\hline Cephalic space* & $3.75: 5$ & 4.25 & $2.5: 5.25$ & 3.50 \\
\hline Nerve ring* & $45.5: 65$ & 62 & $55.25: 75$ & 70 \\
\hline Excretory cell* & $80: 100$ & 98 & $55: 95$ & 85 \\
\hline Anal pore* & $199: 239$ & 210 & $216.6: 266.66$ & 247.5 \\
\hline $\begin{array}{l}\text { Last tail } \\
\text { nucleus* }\end{array}$ & $229: 312$ & 265 & $256.6: 309.16$ & 288 \\
\hline
\end{tabular}

* Microfilarial landmarks are determined from the anterior end.

Table 5: Comparative sensitivity of different techniques for the detection of microfilariae.

\begin{tabular}{|c|c|c|c|}
\hline Technique & Tested & Positive & Sensitivity $\%$ \\
\hline Wet Blood Film & 21 & 9 & 42.85 \\
\hline Thick blood film & 21 & 7 & 33.33 \\
\hline Haematocrit test & 21 & 6 & 28.57 \\
\hline Modified Knott's & 21 & 14 & 66.66 \\
\hline
\end{tabular}



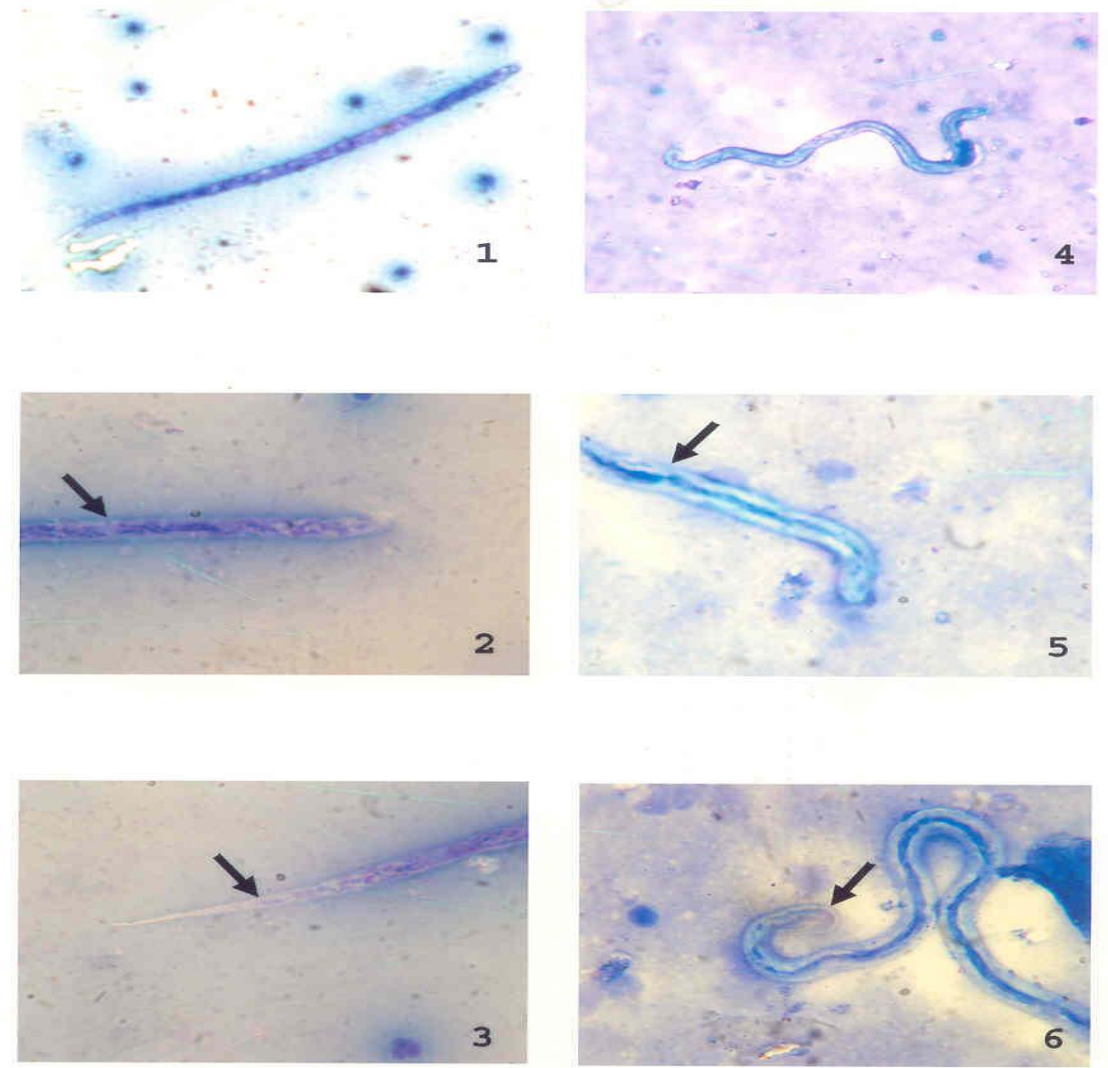

\section{Plate 1: Microfilariae of dogs (Stained with Giemsa stain)}

1- Dirofilaria immitis microfilaria x 100.

2- Anterior end of D.immitis showing nerve ring (arrow) x 1000

3- Posterior end of D.immitis microfilaria showing straight tail (arrow) x 1000

4- Dirofilaria repens microfilaria x 100.

5- Anterior end of D.repens microfilaria showing nerve ring (arrow) $\mathrm{x} 1000$.

6- Posterior end of D.repens microfilaria showing button shaped tail (arrow) x 1000 

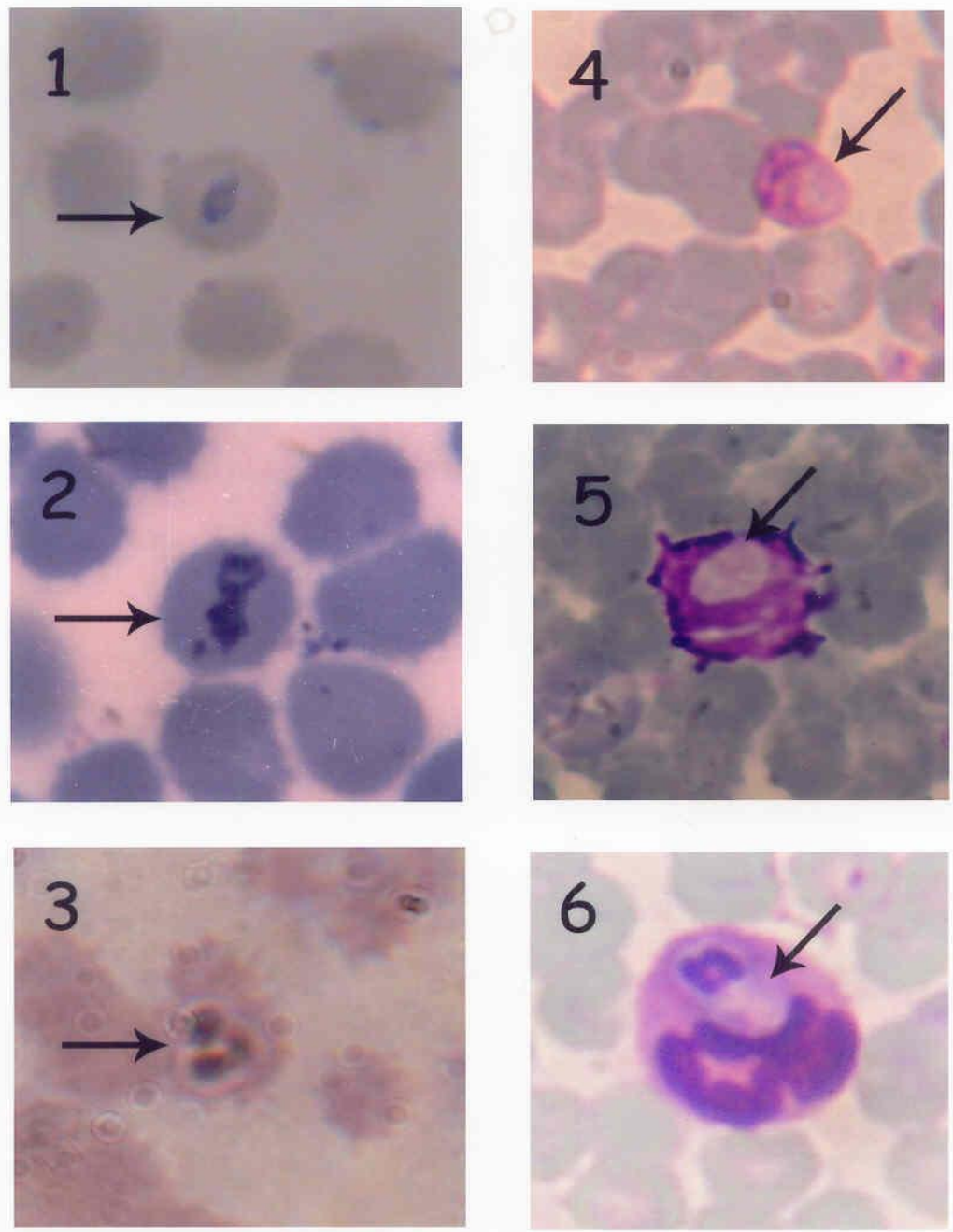

Plate 2: Different forms of protozoan blood parasites in blood films of naturally infected dogs (Giemsa stained).

Fig. 1-3: Different forms of Babesia canis X1000. (arrow)

Fig. 4-5: Macrogametocytes of Hepatozoon canis in blood films of dogs (arrow) X 1000

Fig. 6: Microgametocytes of H.canis in blood films of dogs X 1000 (arrow) 


\section{DISCUSSION}

The parasitic diseases caused by blood parasites are found all over the world and may be causing severe infection in dogs. Each year thousands of dogs become disabled or die from problems caused by blood parasites (Gadahi et al., 2008).

In the present work out of 145 examined dogs 95 (65.51\%) were infected with one or more parasitic species. The infection rate of stray dogs with different blood parasites was $72 \%$ while in foreign breed dogs was $25 \%$. Statistical analysis of the data revealed that a highly significant statistical variations between breeds of examined dogs and the prevalence rate of infection.

High prevalence of blood parasites in stray dogs detected in the present work may be due to the greater exposure of the stray dogs to the vector intermediate host, in addition to the better veterinary services beside the use of prophylactic medication as the best protective measures to the foreign breed dogs. This opinion coincides with Poglayen et al. (1996), Song et al. (2003), and Gadahi et al. (2008).

The total rate of infection with microfilariae was $14.48 \%$. Two species of microfilariae were detected in examined $\operatorname{dogs} D$. immitis and D. repens. Their prevalence rate was $2.75 \%$ and $11.72 \%$ respectively. Both species of microfilariae were detected in the blood films of stray dogs and not detected in examined foreign breed dogs.

Species of microfilariae detected in the present work were reported previously in Egypt by: Mahmoud (1998) who detected D. repens microfilariae in the peripheral blood of $13.3 \%$ of examined stray dogs in Assiut Governorate, Abd-el-Rahim (1998) detected microfilariae of $D$. immitis in the peripheral blood of $42.2 \%$ foreign breed dogs in Assiut city, Ahmed et al. (1986) who detected D. repens microfilariae in $1.27 \%$ of examined dogs in Abu. Roash in Giza province. In the present work detection of both types of microfilariae in Assiut Governorate may be attributed to the methods of diagnosis and the high number of the examined dogs. Also in other countries they were reported by Cancrini et al. (2000), Wu \& Fan (2003) and Rossi et al. (2004).

Our finding fall within the trend of results obtained by various workers mentioned above.

Several factors play an important role in the prevalence of microfilariae in dogs such as: climatic and environmental conditions, humidity and mild fluctuation in day and night temperature. Also the 
unhygienic disposal of manure of animals favors the flourishing of the insect population which plays an essential role in filarial transmission (Samano et al., 1996).

Differentiation between different types of microfilariae by motility via direct wet smear method is difficult, where the microfilariae are unstained and large numbers of cells obscure their view. In the present work among the various techniques used, modified Knott's technique was found to be the most sensitive technique for the detection of microfilariae and its sensitivity was $66.66 \%$. These results confirmed the results recorded by Lindsey (1965), Stein and Lawton (1973) and Todaro et al. (1977).

During the course of the present work no adult filarial worms were detected from 100 dogs at autopsy. The present findings are in agreement with that of Schillhorn (1974) and Mahmoud (1998) who failed to detect D.immitis adult worms in Nigerian dogs and stray ones in Assiut Governorate respectively. Detection of circulating microfilariae without adult $D$. immitis may be due to death of the adults (Newtown 1968), transplacental transmission of microfilariae (Mantovani and Jackson 1968), ectopic infections with adult D.immitis in unusual sites (Otto 1975) or recently terminated infections (Knight et al., 1984). However, Dirofilaria repens adults inhabit subcutaneous tissues, hence the difficulty in getting them.

The prevalence rate of infection with both Babesia canis and Hepatozoon canis was $23.44 \%$ and $27.58 \%$ respectively. Their prevalence of infection among stray and foreign breed dogs was $24 \%$, $31.2 \%$, and $20 \%, 5 \%$ respectively. The same blood parasites (B.canis and H.canis) were detected in the same locality by Sakla (1975) who reported that the natural infection rate of dogs in Assiut city with B. canis and $H$. canis was $7.7 \%$ and $22.7 \%$ respectively.

The morphological characters of B.canis, microgametocytes and macrogametocytes of $H$. canis agreed with description reported by Sakla (1975), Levine (1985), Gossett et al. (1985) and Soulsby (1986).

During the present work it was found that infection of dogs with different blood parasites occur in young as well as in aged dogs but the incidence increase with age in both breeds. This may by attributed to the greatest exposure of the aged animals to the vector intermediate host than young ones. In addition to the low immunity to fight blood-parasite infections in old age, these results coincide with those of (Gadahi et al., 2008). 
Data concerning the seasonal variation on the rate of infection with different blood parasites of dogs showed that the highest rate of infection was during Summer and Spring and the lowest in Winter. Statistical analysis of seasonal variations was highly significant. This might be due to correlation between the infestation and increase in the density of mosquito population and the high peak of abundance of tick vector which plays an essential role in transmission of blood parasitic diseases during such months (Sakla 1973, Todaro et al., 1977 and Samano et al.1996).

Conclusions: Based on the present observations it may be concluded that infection of dogs with different blood parasites is widespread at Assiut Governorate particularly in Stray dogs. The prevalence of infection with blood parasites depending on the age of dogs which increased gradually up to the age of 6 years. Stray dogs usually harbor various parasitic infections due to improper care and unhygienic conditions. Since they did not receive any medicine for treatment so these infections usually persisted for a long time. Such dogs act as a reservoir and carriers of infections for the pet dogs and human being. Prophylactic measures such as accurate diagnosis and proper antihelmintic treatment of imported dogs, in addition to destruction of stray dogs will help in decreasing the risk of infection to other foreign breed ones and humans in the vicinity of infected animals when suitable mosquito vectors are present.

\section{REFERENCES}

Abd El-Rahim, I.H.A. (1998): Canine dirofilariasis among imported dogs in upper Egypt. Assiut Vet. Med. J., 40 (79): 121-130.

Ahmed, B.A.; Amer, O.H. and Fayek, S.A. (1986): New record for Dirofilaria repens (Raillet and Henry 1911). Adult worm and its pathogenesis in naturally infested dogs in Egypt. Zag. Vet. Med., J., XIV. (I): 89-98.

Amer, O.H. (1986): Some studies on filaria in dogs. Ph. D. Thesis, Fac. Vet. Med., Zagazig University.

Baneth, G.; Samish, M.; Alekseev, E.; Aroch, I. and Shkap, V. (2001): Transmission of Hepatozoon canis to dogs by naturally fed or per cutaneously injected Rhipicephalus sanguineus ticks. J. Parasitol., 87: 606-611.

Borenstein, M.; Rothstein, H. and Cohen, J. (1997): Sample power statistics 1.0.SPSS Inc., Chicago. 
Botros, R.W.; Moch, R.W. and Barsoum, I.S. (1973): Babesia canis in an Egyptian balady dog: a case report. J. Egypt. Vet. Med. Assoc., 33: 171-176.

Cancrini, G.; Allende, E.; Favia, G.; Bornay, F.; Anton, F. and Simon, $F$. (2000): Canine dirofilariasis in two cities of south eastern Spain. Vet. Parasitol., 92 (1): 81-86.

Gadahi, J.A.; Arijo, A.G.; Abubakar, M.; Javaid, S.B. and Arshed, M.J. (2008): Prevalence of blood parasites in stray and pet dogs in Hyderabad Area: Comparative sensitivity of different diagnostic techniqes for the detection of microfilariae. Veterinary World.1, (8): 229-232.

Gossett, K.; Gaunti, S. and Aga, D. (1985): Hepatozoonosis and Ehrlichiosis in dog. J. Am. An. Hos. Assoc., 5: 265-267.

Knight, DH. (1977): Heartworm heart disease. Adv. Vet. Sci. comp. Med., 21: 107-149.

Knight, B.H.; Grieve, R.B. and Glickman, L.T. (1984): Proc. Heartworm Symposium 83.Vet. Med. Publ. Co., Edwardsville, Kansas.

Levine, N.D. (1961): Protozoan parasites of domestic animals and man. Minneapolis, Minn: Burges Publishing Company.

Levine, N.D. (1985): Veterinary Protozoology ( ${ }^{\text {st }}$ Ed. Iowa State University Press Ames.

Lindsey, J.R. (1965): Identification of canine microfilariae J.A.V.M.A., 146 (15): 1106-1114.

Lowerence, R. and Thomas, G. (1987): Parasites. Guide to laboratory procedure and identification ( $1^{\text {st }}$ Ed.) American Society clinical pathologist, Chicago.

Mahmoud, A. El-Sayed (1998): Laboratory diagnosis of filariasis in Assiut Governorate, M. Sc. Med. Thesis, Assiut University.

Mantovani, A. and Jackson, R.F. (1966): Transplacental transmission of microfilariae of Dirofilaria immitis in a. dog. J. Parasit. 52:116.

Newtown, W.L. (1968): Longevity of an experimental infection with Dirofilaria immitis in a dog. J. Parasit. 54: 187.

Otto, G.F. (1975): Proc. Heartworm Symposium74. Vet. Med. Publ. Co., Bonner Springs, Kansas.

Pampiglione, S.; Canestri-Trotti, G. and Rivasi, G. (1995): Human dirofilariasis due to Dirofilaria (nochtiella) repens: A review of world literature. Parasitologia, 37: 149-193.

Poglayen, G.; Martini, M.; Bomben, L. and Roda, R. (1996): An updating of the occurance of canine heart worm disease in Northern Italy. Vet. Res. Communications, 20 (4): 303-307. 
Retnasabapathy, A. and San, K.T. (1976): Incidence of canine heart worm (Dirofilaria immitis) in Malaysia. Vet. Rec., 98: 68-69.

Rossi, L.; Ferroglio, E. and Agostini, A. (2002): Use of moxidectin tablets in the control of canine subcutaneous dirofilariasis Vet. Record, (Short communications) 150 (12): 383.

Sakla, A.A. (1975): Studies on ticks in Assiut Governorate with special reference to their role in transmission of parasitic diseases. $\mathrm{Ph} . \mathrm{D}$. Thesis Fac. of Medicine, Assiut University.

Samano, G.R.F.; Najera, F.R.; Herrera, R.D. and Quiroz, R.H. (1996): Prevalence of Dirofilaria immitis in $\operatorname{dogs}$ in six cities in Mexico.Veterinaria Mexico, 27(1) 107-109.

Schillhorn, T. and Van Veen, (1974): Filariasis in domestic animals in northern Nigeria and its relation to human health. In: Parasitic zoonosis, Soulsby, E.J.L. Academic press, New York, pp. 402.

Seo, Youngwoo; Shin, Sungshik; and Kim, Jongtaek (2001): (Occurance of canine heartworm disease in three breeding farms in the vicinity of Seoul, Korea) Korean Journal of Vet. Research, 41 (1) 78: 83.

Song, KH; Lee, SE; Hayasaki, M.; Shiramizu, K.; Kim, DH. and Cho, $K W$. (2003): Seroprevalence of canine dirofilariosis in South Korea. Vet. Parasitol.; 114: 231-236.

Soulsby, E.J.L. (1986): Helminth, Arthropoda and Protozoa of domesticated animals. $7^{\text {th }}$ Ed. The English language book Society Balliera. Tindall and Cassel. London.

Stein, F.J. and Lawton, G.W.B.S. (1973): Comparison of methods for diagnosis and differentiation of canine filariasis J.A.V.M.A., 163(2): 140: 141.

Thrall, DE.; Radertscher, RR. and Lewis, RE. (1980): Radiographic changes associated with developing dirofilariasis in experimentally infected dogs. Am. J. Vet. Res, 41: 81-90.

Todaro, MS.; Morris, C.D. and Heacock, N.A. (1977): Dirofilaria immitis and it's potential mosquito vectors in central New York State. Am. J. Vet. Res, 38 (8): 1197-1200.

Wu Ching Ching, and Fan, Pingchin (2003): Prevalence of canine dirofilariasis in Taiwan. J. Helminthol., 77 (1) 83: 88.

Zahler, M.; Glaser, B. and Gothe, R. (1997): Exotic parasites of dogs: Dirofilaria repens and Dipetalonema reconditum. Tieraztliche praxis, 25 (4): 388-392. 
Assiut Vet. Med. J. Vol. 56 No. 125 April 2010 
Assiut Vet. Med. J. Vol. 56 No. 125 April 2010 